Research Article

Journal of Extension Education

Vol. 32 No. 2, 2020

DOI:https://doi.org/10.26725/JEE.2020.2.32.6485-6491

\title{
Perceived Effects of Adoption of Recommended Practices among Rural Farmers of Nigeria
}

\section{U. Mohammed ${ }^{1}$ and J.J. Pelemo ${ }^{2}$}

\begin{abstract}
The study assessed the perceived effects of recommended practices on levels of hygienic practices, health-care Expenditure, and productive time for Agricultural Activities and children school attendances among the rural farmers in Mokwa Local Government area of Niger State, Nigeria. Multi-stage sampling technique was used to select 311 of rural populace. Data were collected using structured questionnaire as well as interview schedule and analyzed using descriptive statistics. The mean age of the respondents was 46 years while the mean household size was 9 persons. Also, the mean years of experience was 20.8 years while $41.4 \%$ of the respondents had primary education. The mean household income was Nigerian

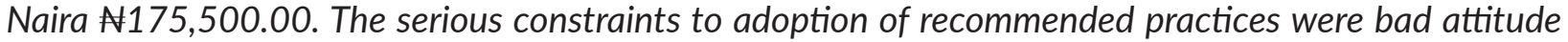
and lack of credit facilities It is recommended that environmental health workers should be empowered to enforce sanctions on noncompliance with adoption of recommended practices and efforts should be made by stakeholders to sustain this channel of sensitization.
\end{abstract}

Keywords: Perceived Effect; Hygienic Practices; Agricultural activity; Nigeria.

\section{INTRODUCTION}

The World Health Organization (WHO) estimated that $60 \%$ ( 80.7 million) of the global burden of disease and 2.8 million deaths per year were attributed to lack of good hygienic practices (WHO, 2019). Related environment diseases such as diarrhea are still a leading cause of mortality and morbidity in children under the age of five. Approximately, 3500 Nigerian children die each year from diarrhea and dehydration (WHO, 2019). During the 2000 's there was a considerable investment in the provision of water supply and sanitation in developing countries.

By 2016, however, a significant proportion of the world's population still remained without access to improve environmental hygiene. In Nigeria, rapid population, growth has not be accompanied by an increase in delivery of essential rural service, such as water supply, sewage and sanitation and collection and disposal of solid wastes. By 2017, it was estimated that only about $20 \%$ of rural population had access to

${ }^{1}$ Department of Planning Research and Statistics, Niger State Ministry of Agriculture, Minna, Nigeria and

2 Department of Agricultural Extension and Rural Development, Federal University of Technology, Nigeria 
reliable water supply of acceptable quality (Federal Ministry of Water Resourses, 2018). Despite some improvements in coverage, a study by the FMWR (2019) reported that in 2018 , only about 10 out of 36 states of the federation had more than 20 litres per capita water supply and good environmental hygiene. In order to ensure strategic approach to realization of the vision statement 20:20:20 on hygienic practices, health care expenditure productive time for agricultural activities and children school attendances in Niger State, Nigeria, the main goals and target set out for the state are:

- Increase in state improved water supply to rural dwellers

- Increase in state improved sanitation coverage to the rural areas and environmental hygiene

- Increase in improved health care expenditure and productive time for agricultural activities

- Increase in children enrolment in schools in the rural area.

This study seeks to describe the socioeconomic characteristics, perception on effect of adoption of recommended practices and constraints of adoption of recommended practices, by the farmers.

\section{METHODOLOGY}

Niger State is located in the Guinea Savannah Ecological Zone of Nigeria. In terms of land mass, it is the largest State in Nigeria. It covers a total land area of $74,224 \mathrm{~km}^{2}$ accounting for about eight percent of
Nigeria's land area. About $85 \%$ of its land area is good for arable crops production (Niger State Geographical Information System, 2015). It is located within Latitudes $8-10^{\circ} \mathrm{N}$ and Longitudes $3-8^{\circ} \mathrm{E}$ with a population of about 3,950,249 (NPC, 2006) and with a growth rate of $3.2 \%$, the State has an estimated population of 5,586,000 in 2017 (Niger State Geographical Information System, 2015). Niger State experiences two distinct season dry and wet seasons with annual rainfall varying from $1,100 \mathrm{~mm}$ in the Northern part to $1,600 \mathrm{~mm}$ in the Southern parts. The average annual rainfall is about $1,400 \mathrm{~mm}$. The duration of the rainy season is approximately 180 days. The wet season usually begins in April/May to October, while the dry season starts from November to March. The State has maximum temperature of $29^{\circ} \mathrm{C}$, average temperature of $22^{\circ} \mathrm{C}$ and minimum temperature of $26^{\circ} \mathrm{C}$. The mean average temperature is around $32^{\circ} \mathrm{C}$. Dry season commences in October (Niger State Geograhical Information System, 2015). Most of the communities in the State are predominantly agrarian. Vegetables grown in the State are, Spinach, Pumpkin, bitter leaf and water leaf leave. Tree crops grown are mango, citrus, coconut, cashew, banana and pawpaw.

Multi-stage sampling technique was used for the study. The first stage involved selection of Agricultural Zones in the State. At the second stage, one (1) Local Government Area from Agricultural zone 1 was randomly selected. The third stage involved random selection of Nine communities from the selected LGA. At the fourth stage, 10\% of the farmers were randomly selected from the 
sampling frame of each communities. In all, a total of 311 respondents were selected from the sample frame of the selected communities.

Primary data were used for the study, the data were collected by researchers and trained enumerators using structured questionnaire complimented with interview schedule. Data obtained were analyzed using descriptive statistics such as frequency distribution, percentage, mean score standard deviation and ranking.

\section{FINDINGS AND DISCUSSION}

\section{Socio-economic characteristics of respondents}

Table 1 indicates that the mean age of the respondents was 46.0 years implying that majority of the respondents belong to the middle age, suggesting that the respondents have the knowledge and understanding of hygienic practices as well as productive time for agricultural activities which will make it easier since respondents with middle age class are expected to have had at least the minimum level of formal education with zeal in trying new ideas of handling hygiene issues. This finding agrees with Adamu and Solomon (2018) who reported that farmers with middle age class withstand stress and have better understanding of new innovation. Table 1 further reveals that the mean household size was 8.5. This finding suggests that large household size will reduce family labour and improve livelihood. Table 1 also indicates that the mean income of the respondent in the study area was \#175,500 Nigerian Naira per annum. This result implies that the respondents in the study area are with low income which might affect their level of hygienic facilities like soap, detergents and disinfectants About 41\% had studied upto primary level.

This implies that since respondents had low educational level, they may not appreciate hygienic recommended practices. The mean years of experience falls in between $11 \& 20$ years with mean of 20.8 indicating that the respondents had long years of experience in both productive time for agricultural activities and hygienic practice that will aid in improving their health care and better their standard of living. The result also shows that majority of the respondents (68.4\%) had access to hygienic practice, health care, productive time for agricultural activities and children school attendance that will improve their level of living. Table 1 also shows that $62.7 \%$ of the respondents were visited by extension agents 1-2 times per year.

\section{Perception in effect of adoption of Recommended practices}

Table 2 shows the respondents' perception on effect of adoption of recommended practices. Results show that adoption of recommended practices led to an improvement in their hygienic practices. About $60 \%$ of the farmers agreed that adoption of recommended practice actually led to decrease in their health care expenditure. About $78 \%$ were of the view that adoption of the introduced practices actually led to an increase in their productive time for agricultural activities and $81.0 \%$ of the respondents agreed that the adoption of recommended practices increased children's school attendance in their households, meaning that the respondent 
Journal of Extension Education

Table 1.

Socio-Economic Characteristics of the Respondents

\begin{tabular}{|c|c|c|c|c|}
\hline SI. No. & Variable & Frequency & Percentage & Mean \\
\hline 1 & Age & & & \\
\hline a & $31-40$ & 215 & 69.1 & \\
\hline b & $41-50$ & 80 & 25.7 & 46.0 \\
\hline c & $51-60$ & 11 & 3.5 & \\
\hline$d$ & $>60$ & 5 & 1.6 & \\
\hline 2 & Household size & & & \\
\hline$a$ & $1-5$ & 97 & 31.1 & \\
\hline $\mathrm{b}$ & $6-10$ & 150 & 48.2 & 8.5 \\
\hline c & $11-15$ & 63 & 20.2 & \\
\hline$d$ & $16-20$ & 1 & 3.1 & \\
\hline 3 & $\begin{array}{l}\text { Years of farming } \\
\text { experience }\end{array}$ & & & \\
\hline a & $1-10$ & 53 & 17.0 & \\
\hline b & $11-20$ & 180 & 57.8 & 20.8 \\
\hline c & $21-30$ & 48 & 15.4 & \\
\hline$d$ & $31-40$ & 28 & 9.0 & \\
\hline e & Above 40 & 2 & 0.6 & \\
\hline 4 & Educational level & & & \\
\hline a & $\begin{array}{l}\text { Non formal } \\
\text { education }\end{array}$ & 103 & 33.1 & \\
\hline $\mathrm{b}$ & Primary & 129 & 41.4 & \\
\hline c & Secondary & 48 & 15.4 & \\
\hline$d$ & Tertiary & 22 & 7.0 & \\
\hline e & Adult & 9 & 2.8 & \\
\hline 5 & Income & & & \\
\hline a & Upto $1,00,000$ & 59 & 18.9 & 175,500 \\
\hline $\mathrm{b}$ & $1,00,001-200,000$ & 193 & 62.0 & \\
\hline c & $200,001-3,00,000$ & 51 & 16.3 & \\
\hline
\end{tabular}


Perceived Effects of Adoption of Recommended Practices among Rural Farmers of Nigeria

\begin{tabular}{|c|l|c|c|c|}
\hline Sl. No. & \multicolumn{1}{|c|}{ Variable } & Frequency & Percentage & Mean \\
\hline d & Above 300,000 & 8 & 2.5 & \\
\hline 6 & $\begin{array}{l}\text { Access to extension } \\
\text { contact }\end{array}$ & & & \\
\hline a & Access & 213 & 68.4 & \\
\hline b & No access & 98 & 31.5 & \\
\hline 7 & $\begin{array}{l}\text { Number of } \\
\text { extension visits }\end{array}$ & & & \\
\hline a & $1-2$ & 195 & 62.7 & \\
\hline b & $3-4$ & 32 & 10.2 & \\
\hline c & $5-6$ & 69 & 22.1 & \\
\hline d & Above 6 & 15 & 4.8 & \\
\hline
\end{tabular}

who adopted the recommended practices testified to the fact that they had positive effects on the respondents. The result further reveals that the four effect variable with combined mean score of 15.23 points which is above the cut-off of 10 points set in the measures of dispersion meant that adoption of recommended practices actually had high positive effects on respondents in the study area.
Constraints in adoption of recommended practices

Table 3 shows the distribution of respondents in their multiple responses on what they perceived as their constraints in adopting recommended practices in the study area. These constraints were ranked and the result indicate that negative attitude towards good hygiene was ranked first by $94.81 \%$ of the respondents. This means that

Table 2.

Perceived Effects of Adoption of Recommended Practices on Farmer's level of Hygienic practices, Productive time for Agricultural Activities, Health-care Expenditure and Children's School Attendance

\begin{tabular}{|c|l|c|c|}
\hline SI. No. & \multicolumn{1}{|c|}{ Effects of recommended practices } & Mean score & Percentage \\
\hline 1 & Level of hygienic practices & 4.37 & 90.8 \\
\hline 2 & Level of health-care expenditure & 3.26 & 60.40 \\
\hline 3 & Level of productive time for agricultural activities & 3.79 & 78.80 \\
\hline 4 & Level of children's school attendance & 3.81 & 81.00 \\
\hline
\end{tabular}


Table 3.

Distribution of Respondents based on the Constraints in Adoption of Recommended Practices

\begin{tabular}{|c|l|c|c|c|}
\hline $\begin{array}{c}\text { SI. } \\
\text { No. }\end{array}$ & $\begin{array}{r}\text { Constraints to the } \\
\text { adoption of recommended } \\
\text { practices }\end{array}$ & Frequency* & Percentage & Ranking \\
\hline 1. & Poor living conditions & 258 & 87.10 & 3rd \\
\hline 2. & $\begin{array}{l}\text { Cultural beliefs, norms and } \\
\text { values }\end{array}$ & 197 & 71.00 & 4th \\
\hline 3. & Lack of credit facilities & 267 & 94.70 & 2nd \\
\hline 4. & $\begin{array}{l}\text { Negative attitude towards } \\
\text { good hygiene }\end{array}$ & 289 & 62.31 & 5th \\
\hline 5. & Lack of sanitation staff & 187 & & \\
\hline
\end{tabular}

${ }^{*}$ Multiple responses

despite the knowledge on recommended best practices, farmers' negative attitude towards good hygiene, prevent them from adopting recommended practices. This was followed by lack of credit facilities, to buy some items like soap, disinfectants and build toilet. Poor living conditions which are often overcrowded and without facilities makes it difficult for a respondent who might be willing to adopt recommended practices. From the results it can be concluded that negative attitude towards good hygiene was the biggest constraint in the adoption of recommended practices in the study area.

\section{CONCLUSION}

Findings revealed that adoption of recommended practices was perceived by farmers as having some positive effects on them. Negative attitude towards good hygiene practices, lack of credit facilities and poor living conditions were important constraints to adoption of recommended practices. Based on the findings of these study, the following recommendations are made.

Only $5 \%$ of the farmers had positive attitude towards recommended practices, hence low level of adoption is likely. The environmental health workers should be strengthened to enforce sanctions on noncompliancewithadoption of recommended practices. This can be done through good legislation in the local government counsels by-laws. This will change the negative attitudes especially the practice of open defecation.

Formal education was a significant determinant of adoption of recommended practices, so concerted efforts should be made by stakeholders to sustain this channel of sensitization. 
Perceived Effects of Adoption of Recommended Practices among Rural Farmers of Nigeria

\section{REFERENCES}

Adamu, M.H. \& Solomon, A.F (2018). Basic Hygienic Recommended Practices for Human Activities, International Journal of Hygiene, 22 (9), 12-17

Federal Ministry of Water Resources (2018). National Water Supply and Sanitation Policy Report, 2018

Federal Ministry of Water Resources (2019). National Water Supply and Sanitation Policy Report, 2019

National Population Census (2006).
Information on Nigeria Population,
pp.1-134

Niger State Geographical Information System. (2015). Background information. Retrieved from www.nigersis.com/aboutniger-state.

WHO (2019). UN-Water Global Annual Assessment of Sanitation and DrinkingWater (GLAAS) 2019: Target Resources for Better Results, Geneva: World Health Organization. 